\title{
The Influence of Communication Systems "Komputer (Komunikasipun tersampaikan)" to Students' Communication Capabilities with Communication Impairments
}

\author{
Tirta Ardiansyah, Endang Rochyadi \\ Special Education Department \\ Unniversitas Pendidikan Indonesia \\ Bandung, Indonesia \\ tirtaardiansyah13@yahoo.com,endersyam@yahoo.co.id
}

\author{
Rahman \\ Language Education and Culture \\ Unniversitas Pendidikan Indonesia \\ Bandung, Indonesia \\ rahmanprofupi@upi.edu
}

\begin{abstract}
This research is intended to find out the right system communication of AAC (Augmentative and Alternative Communication) for students with communication impairments or commonly called CCN (Complex Communication Needs). This research is motivated by the existence of students who had communication barriers in one of the Special Schools in the City of Bandung. The method used in this research is experimental method, with a single subject or Single Subject Research (SSR). The sample in this research is a student from a special need school in Bandung city. This research was held in several steps beginning with assessment process to find out the initial ability of students communication and language development, processing data from assessment results, profiling students' communication skills, determining and arrang the right communication system for students. The results showed that the communication system that the researcher called with the name "Komputer" (Komunikasipun tersampaikan) had an effect on the communication ability of students who experienced communication impairments. Based on the results of the implementation of the communication system, it can be seen that the Komputer (Communication Delivered) had a very good impact so that students could communicate with other people.
\end{abstract}

Keywords-Communication Impairments, Komputer Communication Systems (Komunikasipun tersampaikan).

\section{INTRODUCTION}

Every human being is created differently both physical, character and capability. Though they are created differently, essencially, every human is created as an individual being, which means that he/she can live alone and at the same time is also created as social being, which means that to be able to live in social form a human needs help from others [1].

When humans were born into the world, some are born with perfect physical parts and some are born with imperfect physical parts. This is one of the causes of human being experiencing physical obstacles and also being one of the causes of experiencing other obstacles in the development process [2]. People who experience these things so that they have obstacles in having these disabilities are disabilities [3].
There are obstacles, like visual impairment, mental retardation, physical impairment, language impairments, etc. which cause an inability to do something in his life[3]. Of course it causes them to have difficulty in doing activities. For example, children who have intellectual disabilities then inhibit the developmental of their language, and cause them to have obstacles in communicating. Communication is an important thing in life, especially to fulfill their own needs. To overcome these communication impairments, a system is needed to help them communicate. The system is called Augmentative and Alternative Communication (AAC).

Communication is the most important component for every organism to carry out their lives[4]. Through smooth communication, a child will get various kinds of information. Communication is the process of exchanging information, opinions or feelings of someone with others around them [5]. Some children with special needs experience communication disorders, and then this will be an obstacle for their development. Communication problem is one of the early indicators of children development that can affect academic and social outcomes for themselves [6]. Therefore, they need an alternative communication. Alternative communication is a technique that replaces verbal communication for individuals who experience barriers to speech or are unable to communicate through spoken language [7]. A tool or application is needed to support alternative communication which is called augmentative communication. Augmentative communication is the rules and tools / media that can improve verbal communication skills in the reality of daily life [8].

Augmentative and alternative communication is a medium and method used by children who experience communication barriers in order to communicate well and smoothly with those around them [7]. The selection of AAC needs to be considered carefully by paying attention to the communication barriers experienced by individuals. The selected AAC must be easily and conveniently accessible to the user [5]. Based on this, researchers designed a mobile software application to support the programmed AAC system. The Augmentative and Alternative Communication (AAC) system in the form of 
software is also designed to help children who have tried language development programs but still find it difficult to speak in an understandable way [4].

Based on the explanation above we will discuss a case in the subject of Complex Communication Needs (CCN) and a system developed to optimize the ability of subjects with CCN. To support the augmentative and alternative communication system the team designed an application to assist in the implementation of the system, called "Komputer" (Komunikasipun tersampaikan).

\section{METHOD}

The research method is defined as a scientific way to obtain data with specific purposes and uses. In this study experimental research method was used. According to [8], "Experimental research method is a research method used to find out the effect of certain treatments on others under controlled conditions". The method used in this study was an experimental method with a single subject or single subject research (SSR). In this study, the researchers intended to obtain data on the influence of "Komputer" Systems (Komunikasipun tersampaikan) in improving communication skills of children who experience communication impairments.

This research was carried out based on the A-B-A design. This design is a single subject research design in the field of behavior modification which shows a causal relationship between free variables and dependent variables. The free variable in this study is the communication system "Komputer (Komunikasipun tersampaikan)" and the dependent variable (target behavior) is the communication skills of students.

Behavior of the subject's target (target behavior) was measured first repeatedly in the first baseline condition (A1) with a certain period of time, for example weekly, daily, or hourly, then measured in intervention conditions (B); then it was measured again in the second baseline condition (A2). As a control for intervention conditions, it is believed that a functional relationship between the free variable and the dependent variable is stronger [9].

\section{RESUlT AND DISCUSSION}

This research was held in one of the Special Schools in the City of Bandung for student's junior high school, with the following implementation procedures.

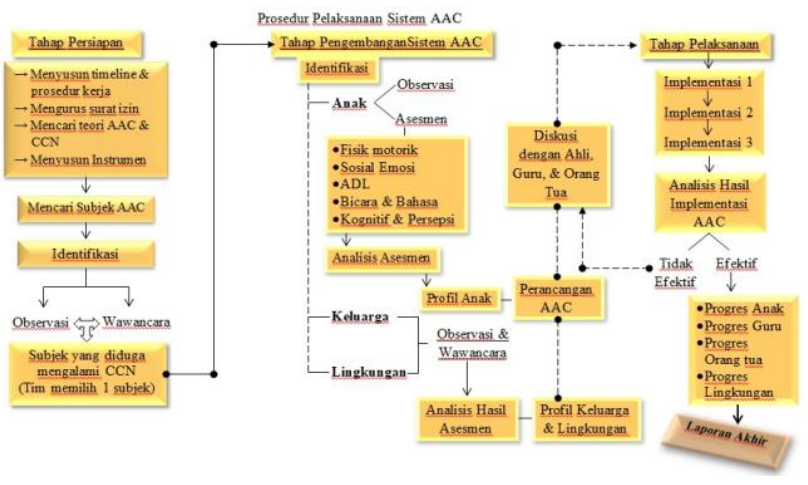

Fig. 1. Research Procedures
The researcher carried out several procedure activities including conducting interviews with classroom teachers and parents at home, observing the daily activities of students both at home and at school (such as learning activities in the classroom, and outside the class during breaks time), making instruments academic and development assessment instruments ranging from cognitive, motoric, social, and language development and communication. Then create student profiles based on assessment results and family and environmental profiles based on the results of interviews and observations.

The next stage was designing an AAC (Augmentative and Alternative Communication) system based on the results of the assessment. In designing the communication system the researchers discussed with experts. Communication systems designed in the form of systematic software resulting in applications that are easy to use. This application can be used on digital media with an Android system. This application was named by the team as "Komputer" which stands for "Komunikasipun tersampaikan". The following are features and steps in using this application:

\section{TABLE I. FEATURES AND STEPS OF USE}

First, the user must turn on the cellphone or tab,
then click the main button which is the symbol
of this application on the cellphone or user tab.




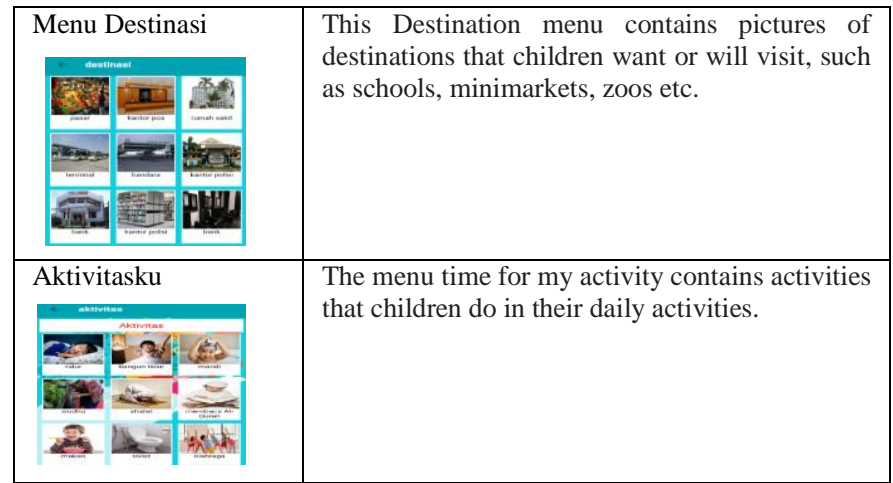

After the communication system in the form of the application has been completed, the next stage is the implementation of the system usage. The first implementation is carried out at home to the subject, parents and other family members so that the system can be used by the subject to communicate with parents and other family members at home. The second implementation is carried out in school to the teacher, and the third implementation to friends, so that the subject can also communicate with all school residents, both teachers and friends in school.

\section{A. The purpose of the AAC system}

The purpose of making this Alternative and Augmentative Communication System is to help children to be able to express their intentions and desires so that children can actively communicate even though they cannot verbally express both verbal and written.

\section{B. Description of the person involved in the AAC system}

For the first step, people involved in the Alternative and Augmentative Communication System are starting from the person closest to the child at home, namely both parents and siblings, and the teacher and friends at school, because the symbols / images in this application are also new including the needs of children in daily activities at home and at school

In the future, it is expected that this AAC system can also be used by children to be able to communicate with people in the environment such as neighbors, or people who have just met children in a new place such as in mini markets, zoos and others.

\section{CONCLUSION}

In the process of developing and implementing an AAC system, a process of determining the subject with the right CCN and an in-depth assessment of the subject's ability to communicate is needed. Then also an assessment about the potential existing in the subject environment is needed. This is done to make the implementation of the AAC system run optimally. KOMPUTER (Komunikasipun tersampaikan) which is an AAC system that the team developed can be said to be a system that helps the process of optimizing communication skills of one subject with CCN. This is seen from the results of the analysis of the implementation of the AAC system, which ultimately makes the subject able to convey what he wants through a tool called KOMPUTER (Komunikasipun tersampaikan).

\section{REFERENCES}

[1] S. Sauri, Pendidikan Karakter dalam Perspektif Islam. Bandung: Rizq Press, 2016

[2] J. W. Santrock, Life-span Development : Perkembangan Masa Hidup., 5 jilid 2. Jakarta: Erlangga, 2002.

[3] D. Kustawan, Pendidikan inklusif \& Upaya implementasinya. Jakarta: PT luxima Metro Media, 2012.

[4] F. L. K. Nida, "Komunikasi bagi anak berkebutuhan khusus," J. Komun Penyiaran Islam, vol. 1, no. 2, pp. 163-189, 2013.

[5] U. D. O. T. Treasury, "Resource Center," vol. 2, no. 1, pp. 137-147, 2016.

[6] A. D. Syndrome, "Early intervention of communication developmen problems in children with down syndrome," vol. 22, 2017.

[7] A. Y. S, "Sistem Komunikasi Augmentatif dan Alternatif untuk Anakanak dengan Autism Spektrum Disorder (ASD) Ayu," 2012.

[8] S. Sugiyono, Metode Penelitian Kuantitatif, Kualitatif dan $R \& D$. Bandung: Alfabeta., 2009.

[9] J. Sunanto, K. Takeuchi, and H. Nakata, Penelitian dengan subjek tunggal. Bandung: UPI Pres, 2006. 